INTER NATIONAL MONETARY FUND
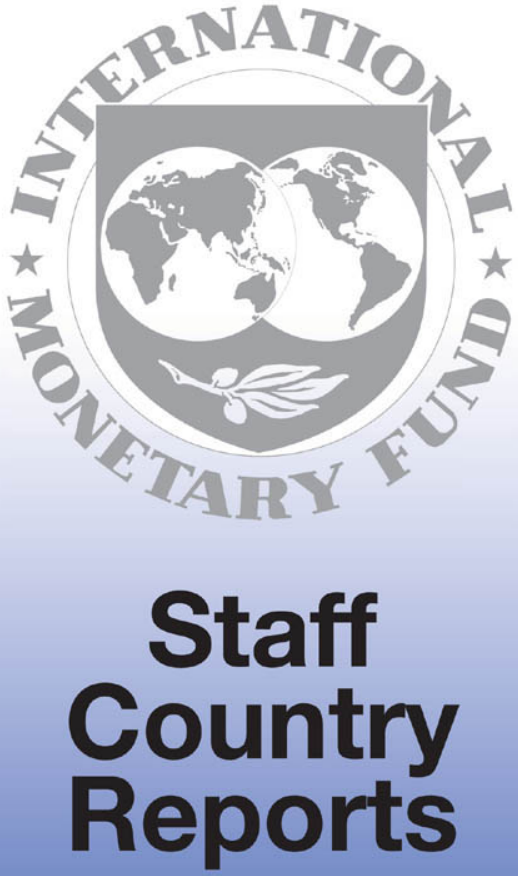


\section{Republic of Serbia: Financial Sector Assessment Program Update- Technical Note on Corporate and Household Debt Restructuring}

This Technical Note on Corporate and Household Debt Restructuring on the Republic of Serbia was prepared by a staff team of the International Monetary Fund as background documentation for the periodic consultation with the member country. It is based on the information available at the time it was completed on March 2010. The views expressed in this document are those of the staff team and do not necessarily reflect the views of the government of the Republic of Serbia or the Executive Board of the IMF.

The policy of publication of staff reports and other documents by the IMF allows for the deletion of market-sensitive information.

Copies of this report are available to the public from

International Monetary Fund $\bullet$ Publication Services

700 19th Street, N.W. • Washington, D.C. 20431

Telephone: (202) 6237430 • Telefax: (202) 6237201

E-mail: publications@imf.org • Internet: http://www.imf.org

\section{International Monetary Fund Washington, D.C.}




\section{FinANCIAL SECTOR ASSESSMENT PROGRAM REPUBLIC OF SERBIA}

\section{CORPORATE AND HOUSEHOLD DEBT RESTRUCTURING}

\section{TECHNICAL NOTE}

MARCH 2010

INTERNATIONAL MONETARY FUND

MONETARY AND CAPITAL MARKETS DEPARTMENT
THE WORLD BANK

FinANCIAL AND PRIVATE SECTOR

DEVELOPMENT

Vice PresidenCy MiddLe EAST AND NoRTH

AFriCA REGION ViCE PRESIDENCY 
Corporate and Household Debt Restructuring ................................................................. $\underline{3}$

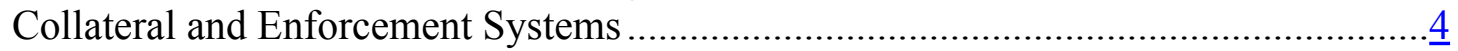

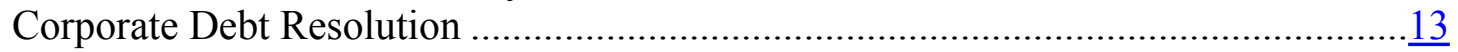

Household Debt Resolution Mechanisms ....................................................

\title{
TABLES
}

Table 1. Pledge Registry Statistics, 2007-2009 …...........................................................

Table 2. Regional Comparative Bankruptcy Recovery Rates ...........................................

Table 3. Blocked Accounts as of September 30, 2009 .................................................11

\section{BOXES}

Box 1. Turkey's Workout Procedure-The Istanbul Approach .........................................14

\begin{abstract}
ANNEXES
Annex 1. Workout Models Adopted in Asia ............................................................... 18
\end{abstract}

Annex 2. Common Components of a Functional Workout Environment ............................19 


\section{CORPORATE AND HOUSEHOLd DEBT RESTRUCTURING}

\section{As of June 2009, nonperforming loans (NPLs) in the banking system constituted} 16.5 percent of total loans, owing primarily to the corporate sector. This marks a significant increase over 2008 and, despite a strongly capitalized banking system, underscores a troubling trend. In the current recessionary environment, more businesses are likely to encounter financial distress due to a decline in demand, shrinking revenues and untimely payments from their own debtors and customers. The situation is compounded by a severe tightening of credit in the banking system and an account blocking procedure that allows creditors holding bills of exchange rapidly to block a debtor's accounts pending repayment. This frequently triggers a race to the bank by other similarly situated creditors concerned about the company's declining financial health. A 75 percent increase in corporate account blockages over the past year evidences the deepening impact of the crisis on the corporate sector.

\section{The Credit Bureau, maintained by the Association of Serbian Banks, also discloses} dramatic increases in corporate and retail defaults over the past year. Accessible by permission of the borrower, the registry contains current information on all bank and leasing credits and their payment status for legal entities, entrepreneurs, and individuals. The private registry functions efficiently and promotes greater transparency and a stronger credit culture for credit providers. In addition to its general function, the bureau sorts data for the National Bank of Serbia (NBS) on corporate and retail aggregate lending and default levels. Data reveals that overall bank credits have increased by a nominal 1 percent from September 2008 to October 2009, while total debt in default increased from 5.4 percent to 11.2 percent. For retail borrowers, total debt over the same period increased by only .3 percent, actually declining for cash and agricultural loans, while retail debt in default increased from 3.9 percent to 6.6 percent.

3. NPL resolution and loan loss mitigation is hampered by a still evolving but uneven collateral and enforcement framework that complicates restructuring and leads to delays and lower recoveries in execution procedures. Some collection mechanisms, like the blocked account process, work almost too efficiently contributing to financial problems. In general, the process of taking and registering collateral has been much improved since the 2005 Financial Sector Assessment Program, while court proceedings and the process of enforcement continue to cause delays. Similarly, collective procedures for bankruptcy and reorganization are costly, ineffective, and widely shunned as being unreliable. These systems provide the context for resolving corporate and household debt. Ineffective and inefficient systems typically render the recovery and resolution process more costly and uncertain. As described below, there is scope for further improvement.

4. Corporate debt resolution is further complicated by a pattern of corporate misconduct designed to circumvent a creditor's legitimate enforcement rights. This is 
particularly acute in response to account blockages. In an effort to survive, business owners frequently engage in a pattern of corporate fraud to avoid their legitimate obligations by creating alter ego or shell companies through which to conduct their ongoing business activities, with all funds passing through the new legal entity. That entity is free from debt and can open bank accounts, engage in contracts, and carry on business as usual using the corporate assets of the prior legal entity under cleverly disguised lease or contractual use obligations. In most modern economies, such practices constitute fraud or fraudulent transfers that can carry stiff penalties, including loss of business privileges. Other reported abuses include applying for voluntary dissolution during which the owner or a friendly receiver continues to operate the business for years in an "apparent" wind-down of the business, while ignoring creditor claims.

Collateral and Enforcement Systems

5. The legal environment for creditors has improved considerably in recent years. New or amended laws have been introduced for Mortgages (2005), ${ }^{1}$ Pledges of Movable Assets (2003, amended in 2005 and 2006), ${ }^{2}$ Financial Leasing (2003, amended 2005), ${ }^{3}$ Enforcement Procedure (2004, undergoing revision), ${ }^{4}$ and Corporate Bankruptcy (2004, amendments recently submitted to Parliament). ${ }^{5}$ Most of these laws largely comport with international norms, although clearly there is some scope for improvement based on practice and interpretation, which is normal.

6. Transfer of land ownership data to the new electronic cadastre is nearly complete, providing a vastly means to trace land ownership rights. Transfer of data to the new electronic cadastre has been underway for a number of years now and is mostly complete. A number of problems have plagued the use of land as collateral arising from distinctions between socially-owned land (urban) and agricultural privately owned land (rural), restitution challenges, illegal constructions, poorly maintained land records maintained by hand, and multiplicity of non-integrated registries and cadastres. Changes in the laws and the new cadastre registry system have resulted in enormous advances in the reliability of land as collateral. Several shortcomings persist. The cadastre does not record buildings illegally constructed on properties without a permit, which is to be remedied in the coming 6-12 months. Property valuations were frequently inflated in the high growth pre-crisis years. While mortgage foreclosure procedures have improved, allowing non-judicial foreclosures, the judicial foreclosure process can still be delayed by as much as eight months due to difficulties in achieving service of process. And even

\footnotetext{
${ }^{1}$ Law on Mortgages, Official Gazette of the Republic of Serbia No. 115/2005, which became effective in February 2006.

${ }^{2}$ Law on Pledge of Movable Assets Registered in the Pledge Registry, Official Gazette of the Republic of Serbia Nos. 57/2003, 61/2005 and 64/2006.

${ }^{3}$ Law on Financial Leasing, Official Gazette of the Republic of Serbia Nos. 55/2003 and 61/2005.

${ }^{4}$ Law on Enforcement Procedure, Official Gazette of the Republic of Serbia No. 125/2004.

${ }^{5}$ Bankruptcy Law, Official Gazette of the Republic of Serbia Nos. 84/2004 and 85/2005.
} 
non-judicial foreclosures are needlessly drawn out due to the requirement for multiple auctions at prescribed discounts from appraised values.

7. A new modern electronic registry system supports pledges of movable assets. A new electronic pledge registry on movable assets and rights began operating in August 2005. The registry is maintained by the Business Registers Agency and considered to be highly efficient, providing for first-in-time registration priority. A novel feature of the Pledge Law provides that pledge instruments timely registered carry self-executing status that enable pledge holders to proceed directly to the execution stage, by-passing the court. However, the actual process of execution continues to be delayed due to an insufficient number of enforcement agents and evasion tactics of borrowers seeking to avoid service by the agents of the execution notice. As indicated in the following chart, the number of pledge applications has steadily increased and, as of October 20, 2009, the Business Registers Agency reports 52,872 active registered pledges securing claims exceeding EUR 17 billion.

Table 1. Pledge Registry Statistics, 2007-2009

\begin{tabular}{|l|l|l|l|l|}
\hline \multicolumn{2}{|l|}{ Pledge Description/Category } & $\mathbf{2 0 0 7}$ & $\mathbf{2 0 0 8}$ & $\begin{array}{l}\mathbf{2 0 0 9} \\
\text { (Jan 1-Sept 30) }\end{array}$ \\
\hline Total registration applications & 14,332 & 20,651 & 21,041 \\
\hline Total number of registered pledges & 11,799 & 16,972 & 17,193 \\
\hline \multirow{2}{*}{$\begin{array}{l}\text { Assets } \\
\text { Covered }\end{array}$} & Vehicles & $34.41 \%$ & $40.03 \%$ & $52.7 \%$ \\
\cline { 2 - 5 } & Machinery/equipment & $39.32 \%$ & $37.88 \%$ & $31.8 \%$ \\
\cline { 2 - 5 } & Other & $26.27 \%$ & $22.09 \%$ & $15.5 \%$ \\
\hline \multirow{3}{*}{$\begin{array}{l}\text { Pledge } \\
\text { Holders }\end{array}$} & Banks & $55.31 \%$ & $67.49 \%$ & $81.81 \%$ \\
\cline { 2 - 5 } & Tax Authorities & $16.86 \%$ & $10.05 \%$ & $6.32 \%$ \\
\cline { 2 - 5 } & Natural Persons & $0.47 \%$ & $0.22 \%$ & $0.44 \%$ \\
\cline { 2 - 5 } & Others & $27.36 \%$ & $22.24 \%$ & $11.43 \%$ \\
\hline Disputes lodged to begin settlement & 69 & 159 & 199 \\
\hline
\end{tabular}

Source: Business Registers Agency.

\section{Enforcement and Execution Problems}

8. While significant progress has been made in shortening the time required to obtain a judgment and a writ of execution, the biggest problem continues to be the inability to obtain a timely enforcement. A new Law on Enforcement Procedure was enacted in November 2004 with great promise. The new law strengthened rights of creditors in seeking enforcement in a number of ways, by including: (a) new protective measures (e.g., injunctions); (b) summary execution procedures for commercial matters; (c) clearer rules and time-bound procedures for appeals; and (d) procedural enhancements to streamline the handling of claims for movable and immovable property.

9. Despite improvements to the Law on Enforcement Procedure, the enforcement process largely fails due to a severe shortage of trained enforcement officers. Inefficiencies 
in the system have been identified by the World Bank and other donor agencies. ${ }^{6}$ Not surprisingly, one donor advisor working in this area found that 73 percent of companies surveyed "never or rarely" used the court for enforcement due to system failure, ${ }^{7}$ recovery rates in commercial court cases were under 5 percent, and the average case for commercial enforcement takes more than 500 days. ${ }^{8}$ Even the European Court of Human Rights has weighed in on several prior occasions criticizing inefficiencies in Serbia's judicial enforcement system that impact protection of individual and property rights. For banks, the current system hinders debt recovery and resolution. Small businesses are unable to collect from larger businesses content to use their resources to delay or avoid payment. Employees are unable to collect wage orders from employers. These weaknesses also discourage foreign investment and ultimately add to the overall cost of credit.

\section{Proposed amendments to the law were submitted in October 2008 to further} improve the enforcement process. The proposed amendments address procedural shortcomings in the law and would introduce a well-regulated system of professional enforcement officers. Specifically, the proposed amendments are designed to streamline service of process rules, provide a more regulated appeals process, provide more flexible minimum sales price rules for public auctions, simplify court jurisdictional rules, eliminate provisions that led to improper delays and obstacles, such as requiring consent of co-owners for asset sales, permit simultaneous enforcement methods, and discretion by the enforcement professional to change enforcement methods without having to obtain additional court approval. Adoption of the proposed amendments should be made a priority.

\section{Bankruptcy and Reorganization Procedures}

\section{The Bankruptcy Law is broadly consistent with best practice principles, but the} actual practice has proven costly, inefficient and unreliable. When adopted in 2004, the present law constituted a major overhaul of the prior law, incorporating features and principles of modern insolvency laws in line with international standards as reflected in the World Bank's Principles and Guidelines for Effective Insolvency and Creditor Rights Systems, and

\footnotetext{
${ }^{6}$ The World Bank's Doing Business 2010 Report found that it takes on average about 635 days to enforce a contract in Serbia, ranking Serbia 23rd out of the 27 countries surveyed in Eastern Europe and Central Asia. Notably, comparative rankings are not necessarily dispositive of the totality of the functioning or efficiency of a country's system, since the assessments are based on a partial assessment of legislation applicable to a narrow set of hypothetical actions, and are not based on actual empirical results. Efforts are underway in Serbia by BAH to introduce methodologies for tracking the length of time that it takes for cases to be completed across all jurisdictional regions of Serbia. Initial findings support the conclusions that the weakest aspect of the system continues to be the enforcement stage.

${ }^{7}$ Bankruptcy and Enforcement Strengthening Project (BES), funded by USAID, study commissioned in 2006.

${ }^{8}$ Bankruptcy and Enforcement Strengthening Project (BES), funded by USAID, studies commissioned in 2007 and 2008.
} 
UNCITRAL's Legislative Guide on Insolvency. The conceptual framework of the law is reported to work reasonably well, although there have been relatively few cases, and those that pass through the process do so less swiftly and at higher cost than in other countries. Efficiency indicators suggest that Serbia's insolvency process is unduly long, recovery rates are lower, and costs are considerably higher on average relative to the efficiency of systems in neighboring countries and the OECD. This suggests that the functioning of the process is sub-optimal.

\section{Low recovery rates are attributed to late opening of cases due to disincentives to}

open a proceeding. Creditors see the process as an inefficient form of enforcement that saddles them with excessive costs, as petitioning creditors are obliged to pay initial court fees for commencing the process and underwriting administrative costs until the case can be selfsustaining. Secured creditors also complain of a pattern of having their rights under the law disregarded. For example, the law exempts collateral from the stay where it is not needed for reorganization or a sale of the business, and requires administrators to gain secured creditor approval to sell their collateral. In practice, administrators and courts often disregard this requirement, giving wide latitude to an administrator's rights to dispose of the estate, relying in part on an administrator's ability to sale collateral in connection with a sale of the business or an operational unit of the business as a whole. The grievances relate to sales that are not of the protected type, and apparently no effort is made to ensure adequate protection of the collateral while in the administrator's use and possession. Effectively, a creditor's collateral can be held hostage to the process. The average age of all pending bankruptcy cases is approximately 2.7 years, with cases filed in Belgrade taking, on average, 4.3 years. As Table 2 reveals, Serbia's bankruptcy process yields lower average returns to creditors and costs considerably more than other countries in the region.

\section{Delays in proceedings are attributed to a number of direct and indirect influences.}

Direct influences include unclear legal remedies, creditor passivity, inefficient enforcement and court rulings, and keeping proceedings open pending a resolution of litigation or a realization under the reorganization plan. Indirect influences causing delay include breach of deadlines by the courts and parties, inconsistent applications of the law, unclear rights to assets, and lack of proper supervision for bankruptcy administrators. Most of the proposed amendments appear designed to address these shortcomings. The proposed changes do not alter the Law's fundamental concept. Rather, they are intended to refine and clarify aspects of the process to promote greater efficiency and reduce costs. 


\begin{tabular}{|c|c|c|c|c|}
\hline Table 2. Regional Comparative Bankruptcy Recovery \\
\hline Country & $\begin{array}{c}\text { Time } \\
\text { (Years) }\end{array}$ & $\begin{array}{c}\text { Recovery rate } \\
\text { (\% of nominal) }\end{array}$ & $\begin{array}{c}\text { Cost } \\
\text { (\% of estate) }\end{array}$ \\
\hline Serbia & 2.7 & 25.4 & 23 \\
\hline Bulgaria & 3.3 & 32.1 & 9 \\
\hline Romania & 3.3 & 29.5 & 9 \\
\hline Croatia & 3.1 & 30.5 & 15 \\
\hline OECD & 1.7 & 68.6 & 8.4 \\
\hline Germany & 1.2 & 52.2 & 8 \\
\hline
\end{tabular}

Source: World Bank Doing Business 2008.

\section{The proposed amendments will introduce more detailed provisions to support} accelerated reorganizations using prepackaged plans. Prepackaged reorganization plans are prepared in advance of the bankruptcy commencement to expedite the reorganization process. Typically, these plans are the product of pre-negotiation and settlement on terms of treatment for particular creditors or classes of creditors whose claims must be resolved to enable the enterprise to be rehabilitated. In the vast majority of cases, pre-packaged plans are used where the enterprise is operationally sound but needs to clean up its balance sheet by restructuring its financial obligations, known as financial restructurings, as opposed to operational restructurings. The other added advantage of a pre-packaged reorganization plan is that it minimizes the amount of time spent in a proceeding, and thereby the impact that the proceeding will have on its business and business relationships.

15. The elaborated pre-packaged plan provisions will help clarify the process, but will impose unduly burdensome creditor impairment criteria that may render the entire process impractical. To avoid having to include unaffected creditors in the process, the proposed amendments currently require the debtor to pay such creditors "in cash" upon closing, even where such creditors are to be paid according to the strict terms of their contracts. This outcome results in a de facto inclusion of all creditors in every pre-packaged plan case, which will potentially undermine and render impractical the new process. It would unduly complicate

\footnotetext{
${ }^{9}$ Notably, the comparative data in the Doing Business report should be viewed as somewhat relativistic, due its narrower scope in partially assessing the legal, institutional and regulatory frameworks and its comparative focus on a small subset of legal proceedings. The World Bank offers a more comprehensive and detailed review of legal systems in its Reports on Observance of Standards and Codes program, which examines the effectiveness and functioning of legal, institutional and regulatory components of a system and its applications in practice. Such an assessment is encouraged and could be a valuable benchmark of performance against accepted international norms and best practices.
} 
the procedure and drive up costs by requiring a complete claims submission and calculation process, and a full creditor vote solicitation, tabulation, and participation by the entire creditor body. As described below, such a result could also undermine the benefits of workout agreements where the parties need to resort to the pre-packaged plan process to bind minority creditors and obtain court approval of plan dispositions, exchanges, or transactions.

\section{Voluntary Corporate Dissolution Abuses}

\section{Voluntary company dissolution procedures are frequently abused to delay creditor} recovery and enforcement actions. The company law, as in most developed systems, provides for a voluntary dissolution. These provisions are important, typically providing for an orderly exit from the market for "solvent" companies that are capable of paying creditors in full. The current process has been abused by companies to avoid payment of creditor claims, as companies filing for voluntary dissolution have been allowed to continue operating without having their accounts blocked or claims enforced. The voluntary dissolution process requires that creditors submit their claims to the receiver for verification and allowance. Routinely, the receiver either is the owner of the company or a friendly insider appointed to act on behalf of the owner. Bank creditors report that their legitimate claims have been ignored, delayed, or contested by the receiver, forcing the creditor to pursue court enforcement remedies and resulting in further collection delays. Moreover, a creditor can petition for an involuntary bankruptcy to have the informal receiver replaced by a formal administrator, but the costs and delays inherent in the formal insolvency process make this solution undesirable. These and other corporate abuses designed to avoid creditor obligations should be subjected to stiff penalties and liability.

\section{Corporate Account Blockages}

\section{The blocked account mechanism is a carryover from the former social economy that} has become an entrenched tool for debt collection. The blocked account process, authorized by the Law on Payment Transactions, ${ }^{10}$ relies on simple one page bills of exchange or debit authorizations demanded by certain credit providers. The process is administered by the Collection Enforcement Agency of the NBS and is highly efficient, giving priority to first in time movers. Under the Payment Law, there are three classes of priorities for account blockages: tax claims, court decisions, and bills of exchange (BEs). The latter are also referred to as promissory notes and routinely used by banks who request signed blank BEs to be completed with the amounts and dates prior to submission to the NBS in the event of a default. The priority structure and process may in fact undermine registered pledge priorities in cash collateral, such as designated cash accounts or proceeds from the sale or disposition of pledged assets that have been deposited into an account. The absence of assurance in the protection of a cash management account with a primary lender leads to a rush to block by creditors and contributes to the demise of a company. As suggested below, it would be useful to have some control over a managed

\footnotetext{
${ }^{10}$ Official Gazette of the Former Republic of Yugoslavia Nos. 3/2002 and 5/2003; and Official Gazette of the Republic of Serbia Nos. 43/2004 and 62/2006.
} 
account that gives assurance to the company for cash needs, while holding the borrower accountable.

18. The deepening impact of corporate distress is underscored by a 75 percent increase in corporate account blockages over the past year. As of end September 2009, the NBS Enforcement Department registered blocked accounts for 63,453 entities on nominal claims exceeding RSD 286 billion (USD 4.7 billion) with additional interest of RSD 344 billion (USD 5.6 billion). Of the total nominal amount, the debt is divided among the priority classes as follows: $1^{\text {st }}$ ) tax authorities-25 percent; $2^{\text {nd }}$ ) judgment creditors-15 percent; and $3^{\text {rd }}$ ) bills of exchange- 60 percent. BE debts are comprised of 75 percent by banks and 25 percent by other creditors. Thus, banks constitute 45 percent (RSD 129 billion/USD 2.1 billion) of the total nominal debt subject to blockage. Large enterprises account for only 122 blocked accounts, representing approximately RSD 45 billion (USD 740 million) of debt due under BEs, while medium enterprises account for 533 blocked accounts, representing RSD 50 billion (USD 820 million) under BEs. The balance in the BE category is represented by approximately 63,650 small enterprises, entrepreneurs, not-for-profits entities, and other small or individual entities that make up about RSD 90 billion (USD 1.475 billion). Small and medium-sized enterprises and entrepreneurs are most likely to walk away or create alternate companies to continue operations, which results in a growing backlog of blocked accounts on defunct businesses. 
Table 3. Blocked Accounts as of September 30, 2009

\begin{tabular}{|c|c|c|c|c|c|c|c|}
\hline & & $\begin{array}{l}\text { Accts } \\
\text { Blocked }\end{array}$ & $\begin{array}{l}\text { Blocked } \\
\text { amount }\end{array}$ & Interest & $\begin{array}{l}\text { Priority } 1 \\
\text { (tax } \\
\text { authorities) }\end{array}$ & $\begin{array}{l}\text { Priority } 2 \\
\text { (court } \\
\text { decisions) }\end{array}$ & $\begin{array}{l}\text { Priority } 3 \\
\text { (Bills of } \\
\text { Exchange) }\end{array}$ \\
\hline & Large & 122 & $52,602,913,560$ & $6,173,806,388$ & $\begin{array}{l}4,295,792,66 \\
7\end{array}$ & $2,766,955,807$ & $45,540,165,085$ \\
\hline Legal & Medium & 533 & $68,236,681,340$ & $\begin{array}{l}273,764,949,99 \\
8\end{array}$ & $\begin{array}{l}10,567,123,4 \\
86\end{array}$ & $7,388,618,258$ & $50,280,943,841$ \\
\hline Entity & Small & 15088 & $96,891,086,661$ & $35,912,359,641$ & $\begin{array}{l}26,201,935,8 \\
47\end{array}$ & $\begin{array}{l}20,016,655,24 \\
5\end{array}$ & $50,647,094,151$ \\
\hline & $\begin{array}{l}\text { not-for- } \\
\text { profit }\end{array}$ & 8825 & $49,668,764,403$ & $21,171,174,007$ & $\begin{array}{l}22,418,929,9 \\
01\end{array}$ & $9,556,400,032$ & $17,693,434,469$ \\
\hline Entre & preneurs & 25136 & $11,832,374,008$ & $1,993,063,398$ & $\begin{array}{l}4,154,933,64 \\
0\end{array}$ & $1,380,903,927$ & $6,296,224,434$ \\
\hline \begin{tabular}{|l|} 
Legal \\
unkno
\end{tabular} & $\begin{array}{l}\text { form } \\
\text { wn }\end{array}$ & 14588 & $7,167,169,292$ & $4,847,231,105$ & $\begin{array}{l}3,770,460,88 \\
8\end{array}$ & $1,606,510,896$ & $1,790,668,331$ \\
\hline TOTAL & & 64292 & $\begin{array}{l}286,398,989,26 \\
6\end{array}$ & $\begin{array}{l}343,862,584,53 \\
9\end{array}$ & $\begin{array}{l}71,409,176,4 \\
31\end{array}$ & $\begin{array}{l}42,716,044,16 \\
8\end{array}$ & $172,248,530,314$ \\
\hline
\end{tabular}

Source: NBS Collection Enforcement Department.

19. Banks handle the blocked account process in different ways. Most banks laud the procedure as one of the most efficient and best ways of recovering on an overdue debt. Some banks react more deliberately to defaults taking stock of the client relationship, the cause of the default, and the potential for rapid resolution. Some banks reportedly exploit the process to improve otherwise weak collateral positions. Financial deterioration and adverse material change clauses in loans, combined with cross-default provisions, and enable banks to accelerate their debt so as to submit their own blocking request, compounding problems for financially distressed companies and complicating restructuring efforts.

20. The blocked account process contributes to a pattern of corporate fraud. To avoid the blockage on cash, businesses routinely form new alter ego companies through which to continue business operations. Legal ambiguities and court inefficiencies make it difficult to prevent these activities, which are fraudulent and undermine the integrity of the corporate sector and stability of banking relationships. Some banks informed that they even negotiate and carry on business with the new entity, thus giving effect to these practices. A better approach would be to impose stiff penalties and sanctions on business owners who engage in such conduct while offering solutions to address the problem of blocked accounts. 


\section{The proposal to amend the Law on Payment Transactions to provide for pro} rationing among $B E$ holders should be carefully considered and complemented by other measures designed to promote debt resolution. The NBS proposes to amend the Law on Payment Transactions to establish a registry for BEs and authorizations (collectively, BEs), create a Claim Enforcement Agency, and provide for a pro rata distribution to registered note holders. To encourage a restructuring, a moratorium might be imposed for a period of 15-30 days. The banking community expressed mixed views on the proposal, supporting the idea of a registry, but having reservations about the application of the pro rata mechanism. The mission team supports the idea of registering BEs to promote greater transparency in the use of B/Es, but recommends that the mechanism for accomplishing this be carefully considered to avoid further confusion in the treatment of BEs as a device to secure a pledge over previously pledged assets. For this reason, registration of BEs in the collateral registry should be discouraged as that would clearly signal that B/Es constitute a pledge. The proposal to expand the current credit registry maintained by the Association of Serbian Banks to encompass registered BEs is one solution that would avoid the collateral characterization while promoting greater transparency.

\section{The pro rata mechanism could be difficult to implement in practice and does not} fully address the problems. If all claims in the registry are deemed payable in a proportional amount, the result could lead to a wider default and lingering blocked account situation than is currently the case. Moreover, a reallocation of funds will not generate greater revenue flow or distributions to creditors from the overall system. Some creditors will be better off and others will be worse off on a given day and with respect to a particular borrower, than under current practice. A pro rata allocation would not necessarily discourage the first mover impulse if distributions are pro rated based on blocking requests submitted on a given date with respect to installments due under registered BEs. Rather, there would be the same incentive to submit a blocking request to ensure that one can participate in the pro rata distribution. If not carefully designed, the mechanism could erode lending practices by overriding strict financial covenants, and default provisions related to a company's financial soundness, by rendering such provisions unenforceable in practice based on de facto treatment under the amended law. Notably, pro rating among the BEs would not alter the priorities, so tax authorities and judgment creditors would still be able to prime the rights of BE holders.

23. The pro rata solution is intended to serve as a quasi-workout framework imposing a temporary standstill and discouraging first move impulses that complicate debt resolution. Admittedly, there is a need to impose a standstill and create a framework for creditors to rationally come to a debt restructuring solution. The 15-30 day standstill/moratorium period is too short to reach an agreement among numerous creditors, creates wider implications on expected enforcement procedures, and would not deter the company from engaging in fraudulent conduct to avoid its obligations. On the contrary, it merely delays the inevitable. To better promote restructuring, the proposed changes should be supplemented by more robust corporate workout guidelines, as described in the Corporate Debt Resolution section below. 
Corporate Debt Resolution

24. Corporate debt restructuring mechanisms are insufficient to cope with increasing levels of corporate distress and NPLs. The NBS decision relaxing provisioning rules to encourage debt rescheduling is an important and commendable step in promoting restructuring of corporate debts. Banks can reschedule a borrower's debt and reclassify it as performing after 6 months, provided it is a first time rescheduling and the debtor is not delinquent more than 30 days within the 6-month period. Debt rescheduling alone is an impartial solution to the problem. Deeper financial and operational restructuring of companies may be needed for already overleveraged companies, and increasingly so if the recession is protracted. Further incentives might be given to encourage companies to go through a restructuring or workout procedure, such as favorable tax treatment for debt forgiveness, debt equity swaps, access to priority financing, and accelerated approval. Similar incentives have been introduced in many of the workout frameworks adopted by countries in financial crises after 1997.

\section{Corporate insolvency mechanisms impose high costs on petitioning creditors,} discouraging access to the system, and fail to adequately protect a creditor's collateral rights in bankruptcy. Recent World Bank and other comparative regional studies reveal that creditor recoveries in the insolvency process in Serbia are among the most costly and yield some of the lowest returns in the region. Court procedures are subject to lengthy delays, and it is doubtful whether the court system could cope with a rapid increase in distressed enterprises. Proposed amendments to the bankruptcy law should correct some of these problems, including new provisions to accelerate approval of corporate reorganizations using the prepackaged plan approach. Changes in the law will not automatically translate into improved efficiencies in the handling and administration of cases by the courts, which require improvement in court practices and procedures, capacity building, training exercises, and additional measures applied over a period of years. Indeed, a USAID project has been working in this area for a number of years with positive but only partial effect. It is unlikely that the courts could cope with a sharp increase in the volume of cases arising from current distressed assets.

26. In view of current inefficiencies in administering insolvency cases, the elaboration of new provisions pertaining to prepackaged plans is an important feature of the new law. While the prior law allowed for submission of pre-packaged plans, courts had little understanding of the workings of such plans and were unwilling or reluctant to recognize an approach not supported by detailed procedural rules. The proposed amendments try to rectify this problem, offering a much more detailed roadmap for courts on the handling of such plans that should improve efficiency, if this new elaborated process is embraced in practice. As introduced, the amendments will require broader participation by the creditor body, increasing the length of time involved and increasing the uncertainty in outcome by opening the voting process to creditors whose claims may not be affected, but who could still vote to reject the plan or oppose its provisions. This will causes some unnecessary delays and may even create a disincentive to its use in out-of-court settlements that would need court approval to minimize transaction, regulatory and other risks of the restructuring. Consideration should be given in the 
implementing regulation to narrowing the participation of genuinely "unaffected" creditors so as make the accelerated restructuring quicker, less complicated, and less costly, and to provide an important complement to an out-of-court workout procedure.

\section{The emergence and significance of out-of-court workout schemes. Most out-of-court} workout schemes owe their genesis to the Bank of England's out-of-court workout guidelines, known as the London Approach, containing a set of principles to guide banks and other creditors in their response to a company facing serious financial problems. The London Approach includes arrangements for an informal standstill, during which an independent review of the company's long-term viability and financing needs are carried out. The Bank of England, where invited to do so, acted as a mediator, facilitating discussions between debtor and creditors.

\section{Following the Asian Financial Crisis, workout frameworks modeled on the London Approach were adopted in Indonesia, Malaysia, South Korea, and Thailand. Each of these} workout schemes contain common features, including a standstill or moratorium, a process to review viability and meet interim financial needs, access to a facilitator/mediator as appropriate, rules supporting majority approval, and binding minority creditors to an agreement. Additional incentives were introduced to encourage restructuring and refinancing. Similarly, a workout framework was adopted by the Central Bank in Turkey after its financial crisis, which is described in Box 1 below. In most of these countries, the procedures were mandatory and/or formalized rather than mere guidelines. A process that is more formal, but that generally applies only to the restructuring of bank debt, may be supervised by a bank regulatory authority rather than the courts. As indicated in Annex 1, there are slight variations in how these rules were adopted and applied in the Asian context.

\section{Box 1. Turkey's Workout Procedure-The Istanbul Approach}

The financial crisis in Turkey in 2001 had a far-reaching impact on the financial and corporate sectors. Of the more than 50 banks in the country, 19 were acquired by the State Deposit Insurance Fund. The major state banks-Halk, Vakif, and Ziraat - were restructured at considerable cost to the government. NPLs were estimated at \$18 billion. Although most corporations were not necessarily overly leveraged before the crisis, the substantial devaluation of the Turkish lira left many corporate groups unable to service their debt. A number of reforms were adopted to address the corporate financial distress and to resolve the escalating levels of NPLs. Banking Law 4743 introduced a quasi-formal workout procedure in June 2002, known as the "Istanbul Approach." Law 5092 amended the Execution and Bankruptcy Act, adding a new "Restructuring Corporations and Cooperatives via Reconciliation" process, introduced in February 2004, which is the equivalent of a pre-packaged, pre-solicited plan of reorganization procedure.

The Istanbul Approach followed workout models adopted in Asia. At its heart is a framework agreement signed by 34 financial institutions, including commercial banks, financial intermediaries, intervened banks, and state banks. The framework agreement addressed terms for selecting firms to participate or benefit from the financial restructuring, deferment of credits, granting of new loans and related matters, and enabled creditors to submit to a non-judicial resolution procedure. A separate creditors committee is appointed, directed by a lead bank holding the largest share of credits or as designated by creditors holding 75 percent of the claims. The committee has 90 days to reach an agreement, subject to extensions for a maximum of 90 days.

During the negotiation period a standstill is imposed on actions by creditors to collect on their debts or against collateral. If the approving creditors hold less than 55 percent of the total debt, the case is dropped from the process. 
If the plan is approved by creditors holding between 55-75 percent of total debt, the plan is submitted to an arbitration committee, constituted by the Board of the Turkish Bankers Association, which has authority to review and approve the plan. If the plan is approved by creditors holding more than 75 percent in value of the claims, it is submitted to final agreement and documentation. By the end of 2003, about 34 agreements had been signed, involving $\$ 5.4$ billion, of which 20 were approved, affecting $\$ 4.56$ billion in debt. The process was not used as widely as it could have been.

\section{Proposed Corporate Debt Restructuring Scheme}

\section{A workout scheme would encourage restructuring and potentially promote more} functional, transparent lending relationships, fostering a more rapid recovery among the corporate sector. Current shortcomings in the system include restrictions on debt rescheduling that preclude viable and varied restructuring solutions, delays in conventional enforcement, unreliable and untimely court-supervised collective procedures, an absence of rules to provide a sufficient period of time for restructuring, encouraging transparent review of the business and access to new financing, and to bind minority creditors. A workout framework should address each of these shortcomings so as to promote swift resolution. And because of its ability to address the broader requirements for a speedy debt restructuring, a loan workout framework is an essential pre-condition for the provision of pro rata relief to creditors seeking to block accounts, thereby addressing the issue of a first mover advantage in account blockages and mitigating concerns over problematic corporate behavior designed to bypass account blockages and avoid creditor obligations.

30. Key features of a workout scheme in Serbia should include (a) a brief extendable standstill or moratorium period (30-60 days) to allow negotiation of a restructuring; (b) a process for inter-bank coordination and access to a facilitator, as needed; (c) timely access to relevant information on debtor's business, assets, and liabilities; (d) protection of a collection account, permission for interim use of cash/cash collateral, and access to priority financing; (e) majority approval requirements and rules binding minority creditors; and (f) incentives for participants, such as relaxed classification/provisioning rules and favorable tax treatment for restructured debt (e.g., debt forgiveness, debt equity swaps, and for transferred assets). The workout scheme is generally embedded in a set of guidelines or a decision by the national bank, an inter-creditor agreement among banks, and possible legislation or legislative amendments. For example, proposed amendments to the Payment Law (regarding blocked accounts) and the corporate insolvency law (on pre-packaged plans) should ensure that these laws complement the workout framework. Possible amendments and clarifications may also be required for laws governing provisioning, tax treatment on restructured debt, the pledge law (to clarify cash collateral protections), and corporate law (to introduce stronger sanctions for fraudulent transfers and director/officer liability for engaging in fraudulent corporate conduct). 
Household Debt Resolution Mechanisms

31. The framework for household debt restructuring is much improved with respect to real estate and housing, but suffers from some of the same delays related to court execution of other types of assets. In general, the home loan and mortgage market in Serbia is still relatively young, having been introduced only in the past 5-6 years. Most banks provide lending based on the value of the underlying property and its relative price stability in a particular market or region. Loan to value ratios range from 65 percent to 90 percent, and qualifications are subject to restrictions on an individual's total indebtedness and home loan obligations as a percent of its monthly income. The new cadastre system and mortgage law provide an efficient means for registering security. The one problem noted is that the transition to the cadastre has not been fully completed, which should happen by next year, and consequently buildings constructed on properties without a permit are considered illegal and cannot be registered. Efforts are underway to force the registry and compliance of all such illegal properties within the next 6-12 months, although this deadline represents the third such deadline.

\section{Banks are reasonably well protected on household properties from the National} Mortgage Insurance Corporation (NMIC), which insures a borrower's payment obligations to the lender in the event of default. According to the NMIC, it has insured approximately 45,500 loans throughout the country representing 80-90 percent of the total home loan market. The market is far from reaching a saturation point, and represents enormous growth potential. In the event of a payment default, a bank must give due notice before terminating the contract and commencing foreclosure and auction procedures. Termination can occur after approximately 60-90 days, at which point the NMIC will reimburse the bank for arrearages and assume monthly payments. Upon a sale of the property, NMIC is first repaid for amounts paid to the lender, and any loss is split 75/25 between the NMIC and lender. To date, only two properties are said to have gone to sale, in which the banks were fully repaid. The same level of coverage and protection does not exist everywhere, and some banks have complained of inability to sale properties, especially where property values were highly inflated. Mortgage property represents the best of the banks' collateral, other than cash, for retail lending. Other retail loans are less well protected, including loans to small businesses, entrepreneurs, farmers, consumers, and for autos and credit cards.

\section{Recommendations}

\section{Immediate Priorities}

- Adopt an NBS regulation establishing corporate restructuring framework, specifying guidelines on inter-creditor debt arrangement, blocked accounts treatment, and appropriate incentives, such favorable tax treatment for debt forgiveness, debt equity swaps, access to priority financing, and accelerated approval.

- Adopt proposed Bankruptcy Law amendments to improve efficiency of liquidation and reorganization provisions, with refinements to the proposed prepackaged plan provisions to 
restrict use to affected creditors (pending consideration at this time); and corresponding regulations supporting prepackaged restructurings that also complement and provide an incentive for accelerated processing of out-of-court agreements.

- Amend the pledge law to clarify a creditor's priority in cash collateral and cash collateral accounts.

- Amend the Law on Payment Transactions with respect to blocked account provisions to incorporate changes to accommodate a corporate workout framework, use of cash collateral and cash management accounts, and interim pro rata distribution and standstill treatment.

\section{Short-Term Priorities}

- Create a mechanism for registering BEs, either in the existing credit bureau maintained by the Association of Serbian Banks or in the NBS blocked account database.

- Strengthen enforcement mechanisms by adopting the proposed amendments to the Law on Enforcement Procedure, supported by the establishment of a regulated profession of enforcement officers.

- Amend corporate law to (a) strengthen actions for corporate fraud; (b) provide for avoidance and recovery of fraudulent transfers; (c) introduce director/officer accountability and liability provisions; (d) preclude abuse of corporate dissolution mechanisms to avoid creditor payments, by requirement mandatory receivers to manage dissolution, and/or introducing other creditor protections. 


\section{Annex 1. Workout Models Adopted in Asia}

\begin{tabular}{|c|c|c|c|c|}
\hline & Indonesia & Republic of Korea & Malaysia & Thailand \\
\hline $\begin{array}{l}\text { Name of } \\
\text { arrangement }\end{array}$ & $\begin{array}{l}\text { Jakarta Initiative } \\
\text { Task Force (JITF) }\end{array}$ & $\begin{array}{l}\text { Corporate Restructuring } \\
\text { Agreement }\end{array}$ & $\begin{array}{l}\text { Corporate Debt } \\
\text { Restructuring } \\
\text { Committee }\end{array}$ & $\begin{array}{l}\text { Corporate Debt Restructuring } \\
\text { Advisory Committee }\end{array}$ \\
\hline Basic approach & $\begin{array}{l}\text { Forum selected with } \\
\text { time-bound } \\
\text { mediation }\end{array}$ & $\begin{array}{l}\text { Framework for debtor- } \\
\text { creditor negotiations } \\
\text { and resolution of inter- } \\
\text { creditor differences }\end{array}$ & Forum for negotiation & $\begin{array}{l}\text { Forum for facilitation; } \\
\text { superseded by contractual } \\
\text { approach, that is, "Debtor- } \\
\text { Creditor Agreements" }\end{array}$ \\
\hline $\begin{array}{l}\text { Default for } \\
\text { failure to reach } \\
\text { agreement }\end{array}$ & $\begin{array}{l}\text { JITF may refer an } \\
\text { uncooperative debtor } \\
\text { to government for } \\
\text { possible bankruptcy } \\
\text { petition }\end{array}$ & $\begin{array}{l}\text { Receivership or } \\
\text { liquidation }\end{array}$ & $\begin{array}{l}\text { Foreclosure, liquidation, } \\
\text { or referral to Danaharta } \\
\text { Asset Management } \\
\text { Company with super- } \\
\text { administrative powers }\end{array}$ & $\begin{array}{l}\text { Less than } 50 \% \text { support for } \\
\text { proposed workout, Debtor- } \\
\text { Creditor Agreements oblige } \\
\text { creditors to petition court for } \\
\text { collection of debts }\end{array}$ \\
\hline $\begin{array}{l}\text { Resolution of } \\
\text { inter-creditor } \\
\text { disputes }\end{array}$ & $\begin{array}{l}\text { No special } \\
\text { procedures }\end{array}$ & $\begin{array}{l}\text { After three failures to } \\
\text { obtain } 75 \% \text { creditor } \\
\text { support, plan goes to } \\
\text { seven-person } \\
\text { Coordination } \\
\text { Committee for } \\
\text { arbitration }\end{array}$ & $\begin{array}{l}\text { Persuasion by central } \\
\text { bank }\end{array}$ & $\begin{array}{l}\text { Mediation, per inter-creditor } \\
\text { agreement, if only } 50-75 \% \\
\text { approval; but any bank with } \\
\text { large exposure (for example, } \\
\text { a foreign bank) could opt out }\end{array}$ \\
\hline $\begin{array}{l}\text { Role of central } \\
\text { bank }\end{array}$ & None & $\begin{array}{l}\text { None. But strong } \\
\text { support from Financial } \\
\text { Supervisory Committee }\end{array}$ & Secretariat support & $\begin{array}{l}\text { Not mandated, but central } \\
\text { bank can use influence }\end{array}$ \\
\hline $\begin{array}{l}\text { Support from } \\
\text { legal system }\end{array}$ & None & $\begin{array}{l}\text { Credible threat of } \\
\text { receivership or } \\
\text { liquidation }\end{array}$ & $\begin{array}{l}\text { Credible threat of } \\
\text { foreclosure or } \\
\text { liquidation encourages } \\
\text { good faith by debtors }\end{array}$ & $\begin{array}{l}75 \% \text { creditor threshold both } \\
\text { for workouts and court- } \\
\text { supervised reorganizations; } \\
\text { cram down by court possible }\end{array}$ \\
\hline
\end{tabular}


Annex 2. Common Components of a Functional Workout Environment

A functional workout process includes a number of common features, including:

- Enabling Framework: A functioning restructuring environment depends on a legal framework that facilitates the restructuring plan, such as allowing debt-equity swaps, forgiveness of bank debt and taking of collateral, and authorizing priority financing for new money. The legal framework must also provide proper incentives for the parties to accept treatment that will render the restructured business viable (e.g., favorable offsetting tax treatment for debt forgiveness and debt-equity swaps).

- Neutral forum: a "forum" in which both debtor and creditors can initially come together for the purpose of exploring and negotiating an arrangement to deal with the financial difficulty or insolvency of the debtor. In the Serbian context, this might well include a forum favorable to mediation, similar to the approaches adopted in Asia and under the Istanbul Approach, as opposed to one in the courts.

- $\quad$ Participants: the workout process should involve all key constituencies, generally the lenders group, and sometimes other key creditors who may be affected by the restructuring or are critical to the resolution.

- Coordination: to better coordinate negotiations, a "lead" creditor should be appointed to provide important leadership, organization, and administration. The lead creditor typically reports to a committee that is representative of creditors to assist the lead creditor and to act as a provisional sounding board toward proposals.

- $\quad$ Stabilization: parties need to promptly stabilize the business operations and provide for negotiation period, which is generally reflected by a "standstill" agreement (a contractual agreement to suspend adverse actions by both the debtor and the main creditors) that endures for a relatively short period. This may be compared with the "moratorium" or stay of actions, which is a feature under the formal rescue process in bankruptcy.

- Liquidity and Access to New Money: liquidity is essential to stabilize the business, and may be more difficult to provide in informal workout procedures. This is because formal bankruptcy laws frequently provide for a "super-priority" for ongoing funding of a debtor, but that law does not extend to informal arrangements. In these cases, creditors need to devise a contractual super-priority by means of an "inter-creditor" agreement, which clarifies 
that emergency funding by one or more creditors will rank for repayment in advance of their other respective entitlements.

- Information: access to reliable and accurate information on the business is essential to reaching a consensual agreement, including its business activities, trading position, and general financial statements. This is comparable to the statutory requirement for the provision of similar disclosure found in formal rescue regimes.

- Negotiation, Agreement, and Voting: negotiating, agreeing, and implementing the restructure plan is generally based on agreement among the creditors and the debtor as to the terms and conditions for the restructuring, and acceptance by a requisite majority of creditors. The percentage approval necessary may vary depending on the specific acts undertaken during the restructuring (for example, 75-90 percent for restructuring, 75 percent for moratoriums, 66 percent for capital expenditures, credit draws, and asset sales, and 100 percent for new money). In the case of new money, obviously no lender could be forced to extend new financing against its will. It is recommended that majority thresholds be fair, while at the same time low enough to encourage maximum potential for rehabilitation (e.g., simple majority).

- Legally Binding: the final restructuring agreement is made legally binding on a dissenting minority, providing they are party to an inter-creditor agreement that contractually binds them to the majority decision. Parties who have not bound themselves contractually would not be bound by the decision of majority creditors, which raises a risk that the restructuring could be rendered meaningless by independent action of minority and holdout creditors. In formal proceedings, the statute creates the mechanism for binding minority creditors. Solutions should be considered to provide for a formal binding approval, where needed, such as by use of the pre-packaged plan provisions in the insolvency law. 